\title{
Topo-graphies
}

Roma Sendyka

\section{Prism: Understanding Non-Sites of Memory ${ }^{1}$}

DO|:10.18318/td.2015.en.2.2

$\mathbf{T}$ he idyllic river landscape that opens Claude Lanzmann's Shoah soon becomes scenes in which Szymon Srebrnik guides the filmmakers through the forest in order to finally stand before an empty clearing and say, "Es ist schwer zu erkennen, aber es war hier." [It is difficult to recognize, but it was here.] "Here" is Chełmno/Kulmhof, one of the many sites of genocidal massacres perpetrated between Berlin and Moscow that now contain the remains of the victims. ${ }^{3}$ Forest clearings, clumps of trees, grassy

1 This paper is accompanied by eight diptychs, which can be found in the last 9 pages of the insert $t_{t}$ prepared for the purposes of this publication by Jason Francisco, an artist, essayist, and photographer. Francisco's diptychs raise in visual language questions that the present article sets forward: the contemporary meaning of contested, forgotten memory sites, the usage of the sites, our presence within them, the habitable and the inhabitable, the ordinary and the inconceivable, the conflicts of past and present, life and death, the visible and the invisible.

2 Shoah, Chapter 4, 00:07:05

3 Following the reasoning of Timothy Snyder in Bloodlands: Europe between Hitler and Stalin (New York: Basic Books, 2010), I propose expanding the discussion of "non-places of memory" to refer not only to Holocaust sites but also to the sites of other genocides or of other forms of mass violence, and to sites related to these events (includ-

\section{Roma Sendyka is}

a director of the

Research Center for

Memory Cultures,

teaches at the Center

for Anthropology

of Literature and

Cultural Studies at

the Polish Studies

Department,

lagiellonian

University. She was

awarded in the

Patterns Program

(Erste Stiftung,

Vienna, 2010-12) for

the project "(In)visible

Loss. The Holocaust

and the Everyday

Visual Experience

in Contemporary

Poland and Central

Europe.: She recently published: Prism

- understanding

Non-Sites ofMemory

(Cahiers Parisiens,

Univ. of Chicago

Press, Paris 2014)

and Sites That

Haunt:Afrects and

Non-Sites ofMemory,

which won the

Michel Henry Heim

Translation Prize 2014 and will be published

in East European

Politics and Societies. 
knolls - the residents of Central-Eastern Europe know these places, which on the surface are no different from their surroundings, though there does seem to be something disturbing in the air around them that sets them apart. My question is, what is it? Because it is not the driving force of symbols - of signs posted, or of tombstones - nor the language of ruins. Here nature covers over, transforms, and does not allow the visitor to view the past.

Lanzmann provocatively calls his work a "topographical, geographical" film, ${ }^{4}$ maintaining that it is not possible to really think the problem of the Holocaust without visiting its sites and combining knowledge of events with a spatial experience that is meant to be extended in a sort of reenactment, "hallucinations," attempts at imagining that "nothing has changed": "I was witness to the change," he says, "and yet, at the same time, I had to think that time had not actually completed its task."5 This plane of dual temporality distorts space-time: quiet bends in the river, clearings, mounds become "disfigured sites [les lieux défigurés]" located simultaneously in the "here and now" as well as in the "there and then." Lanzmann defines such spaces as lesnon-lieux de la mémoire (non-sites of memory). Although the idea of "non-site"6 (the image

ing dilapidated areas of towns, abandoned houses, ruined cemeteries, etc.). A full inventory of these places would require further research.

4 Claude Lanzmann, "Le Lieu et la parole," Au sujet de Shoah: Le Film de Claude Lanzmann, ed. Michel Deguy (Paris: Éditions Berlin, 1990), 294: "You have to learn and see. You have to see and learn. They're inseparable. If you go to Auschwitz but know nothing about the place or the history of the camp, you don't see anything, you don't understand anything. By the same token, if you do know but haven't been there, you don't understand anything, either. They have to go together. That's why the issue of places is such a fundamental one. I didn't make an idealistic film full of grandiose musings on metaphysics and theology about what happened to the lews and why they were killed. It's a very grounded film, a film on topography, on geography."

5 Lanzmann, "Le Lieu et la parole," 290: "I call these deformed places non-sites of memory. At the same time, it's essential that the traces endure. I have to give in to hallucinations and think that nothing has changed. I was witness to the change, and yet, at the same time, I had to think that time had not actually completed its task."

6 Nora's term is translated into English as "sites of memory"; its reverse would thus be in English "non-sites of memory." The term "non-places," meanwhile, translates Marc Augé, as in his "non-lieux de la surmodernité." It is worth noting the etymology of the English words "site" and "place." "Site derives from the Latin situs, derived from the verb sinere, meaning 'to set aside, to leave be, to permit,' while place derives from the greek plateîa, meaning 'broad street' or 'open city space.' This is to say that a site, in the original conception of the English language, is a position designated in the action of leaving it or for the sake of being able to leave it, presumably so that it can be found again, which is to say encoding as part of its very designation the possibility of putting it out of mind, leaving it to inactivity, and perhaps to neglect. Place, on the other hand, presumes an experiencing subject there to constitute it as such--an experiencing subject seeing expansively into a location, which becomes a locus of attachment 
of the "voyage to nowhere," to "the unknown") crops up with some frequency in survivors' narratives, ${ }^{7}$ the term, used in the title of a 1986 interview $^{\mathbf{8}}$, is very clearly, according to Dominic LaCapra, ${ }^{9}$ derived from Pierre Nora's conception of "sites of memory." Indeed, abandoned, unmarked sites of destruction do not serve either the local community or any other group as a memory anchor; there is no person whose "imagination would invest them with a symbolic aura," 10 which essentially makes them the opposite of the places catalogued in Les Lieux de memoire (1984-92)/Realms of Memory (1996-98).

I propose here to return to these special places "in spite of everything [ $\mathrm{mal}$ gré tout]"- "in spite of the fact that there is nothing, but nothing, left to see" there. It was Georges Didi-Huberman who, in his essay Lieux malgré tout from the collection Phasmes (1995), 11 proposed replacing Lanzmann's negative term "non-lieu" with "the site despite everything," which possesses a positive valence. He then proceeded to pose the question that, to me, successfully isolates the central problem of these sites; namely, "Why are these sites of slaughter the sites in spite of everything, the sites par excellence, the essential sites?"12

What makes these sites essential? Why and how do we conceive of them as sites despite everything, despite the fact that "there is nothing ... left"? What exactly distinguishes them from the topographical fabric into which they have been sewn-because despite initially appearing to blend in with the surrounding landscape, there is in fact a distancing, an isolation here. Srebrnik was able

and activity. 'Place,' in other words, designates the fullness-in-experience of a 'site' when it is actually inhabited"; see: http://jasonfrancisco.net/to-go-to-Iviv (Feb. 28, 2014).

Cf. Anne Whitehead, Trauma Fiction (Edinburgh: Edinburgh University Press, 2004), 49.

8 François Gantheret, "L'Entretien de Claude Lanzmann, Les non-lieux de mémoire " Nouvelle Revue de Psychanalyse 33 (1986): 293-305

9 "With implicit reference to a phrase of Pierre Nora, he also brings out how the sites that are so important in his film are 'non-lieux de la memoire' in that they are traumatic sites that challenge or undermine the work of memory." Dominic LaCapra, "Lanzmann's 'Shoah': 'Here There Is No Why," Critical Inquiry 2 (1997): 240; Lanzmann's term is now less clear due to the use of "non-lieu" in Marc Augé, Non-Lieux, introduction à une antropologie de la supermodernité: Non-Places: An Introduction to Supermodernity, trans. John Howe, 2nd edition (London: Verso, 2009). (1992). A similar phrase also occurs in Georgio Agamben's Remnants of Auschwitz: The Witness and the Archive, trans. Daniel Heller-Roazen (Zone Books: New York, 1999), 52): nonplace is a site occupied by a Muselmann, with its extreme limit called "selection." Pierre Nora, "Between Memory and History: Les Lieux de Mémoire," Representations 26 (1989): 19. Georges Didi-Huberman, Phasmes: essais surl'apparition (Paris: Minuit, 1995). 
to point out his execution site because it somehow stood out from the rest of the forest: someone had kept nature from completely absorbing this space. "Nonsites of memory" are not-I suggest-permanently forgotten, as Lanzmann alleged:13 there does exist a performatively articulated memory around them, which would make them distant relatives of anti-monuments, ${ }^{14}$ were it not for the radically different origins of the actions performed upon and against them. These sites are actively present in the life of surrounding communities in such a way that they are bypassed, not named, not marked, not built up, unsown - as taboo places. The memory of them is not revealed at the level of material culture-markers are not placed there-but rather by way of negation, in turning away or turning a blind eye, and even through such radical gestures as littering and vandalizing: these acts appear to be related to ritual acts, magic, primal acts intended for cursed spaces, taboo places, which our culture has associated since Roman times (if not before) with death and catastrophe. ${ }^{15}$

The places I have in mind are numerous and diverse, and are the result of a variety of historical cataclysms, not only the Shoah. They are, in essence, burial places - mass graves or killing sites ${ }^{\mathbf{1 6}}$ - while also being sites of executions and of torture (like the terrains of former labor camps, concentration camps, and death camps) that have not been memorialized by being transformed into museums or monuments; and furthermore, places that remain connected to the events of genocide: demolished synagogues, vandalized cemeteries. These places may occur both in the city and in the countryside; they may be small, or even tiny, and they may also be extensive. They may stand out from the surrounding landscape in the sense that they are a kind of breach in its ordinary, familiar structure; they may not stand out at all, being mere clumps of grass or thickets. They share a certain affective aura that is difficult to rationalize - something in these spaces is perceptibly "off."

To develop a working definition of these places, I hazard an indication of a quality they all share: they are a source of a certain discomfort among

13 Ulrich Baer writes about places where "historical knowledge has burned out," see Spectral Evidence: The Photography of Trauma (Cambridge: MIT Press, 2002), 72

14 Cf. James E. Young, Texture of Memory: Holocaust Monuments and Meanings (New Haven, CT: Yale University Press, 1993).

15 Cf. Eli Edward Burriss, Taboo, Magic, Spirits: AStudy of Primitive Elements in Roman Religion (New York: Macmillan, 1931), 66-67. With regard to places, "taboo" referred not so much to prohibiting the disturbance of a site as it did to the behavior of individuals who found themselves on that site. Taboo places (e.g., places struck by lightning) were marked with (for example) stones that would prevent the passerby from accidentally wandering in. 
the communities nearest them, for whom commemorating them is a greater threat for their collective identity than is neglecting to commemorate them, though this, too, puts them at risk of external critique. In other words, these places are not sites of memory in Pierre Nora's sense largely because the populations topographically ascribed to them do not need or even actively do not want to invest their memory in them. They want to forget these locales, to not-remember them. Les lieux de la non-mémoire. Or with the negative particle preceding the entire time, as Lanzmann has it: Les non-lieux de lamémoire.

To address their "fundamental significance," I will give a concrete example: the site of the former German concentration camp at Krakow-Plaszów, which owes its fame to Thomas Keneally's book Schindler's Ark (1982) and to Steven Spielberg's film Schindler's List (1993). ${ }^{\mathbf{1 7}}$ It is estimated ${ }^{\mathbf{1 8}}$ that 25,000 prisoners passed through this camp, and that the remains of $8,000-10,000$ predominantly Jewish victims are still located on these premises. After the war, the area continued to be undeveloped, with abundant vegetation taking its revenge for the period of the almost total destruction of the land during the life of the camp. A monument "in honor of the martyrs killed in Hitler's genocide from 1943-1945"19 stands at the eastern edge of the site. As a result of rapid urbanization after 1989 , the site of the camp, which people had previously perceived as being on the outskirts of the city, suddenly became a part of the very center of the city. Satellite photos on Google Maps show a gaping hole in the fabric of the city here, around the same size as the Old Town of Krakow so very beloved by tourists. These two splotches relate to one another like the twin blots of a Rorschach test, embodying the urban conscious and the urban unconscious, the visible and the invisible, the revealed and the concealed, the familiar and the uncanny.

\section{Above}

In his book Spectral Evidence: The Photography of Trauma, Ulrich Baer reads the image corresponding to the typical "non-site of memory" based on the site

17 The camp began as a work camp in late 1942 and was officially transformed into a concentration camp in January 1943. After expansions, it ultimately occupied 67 hectares. Its liquidation lasted from August 1944 until mid-January 1945.

18 Cf. Ryszard Kotarba, Niemiecki obóz W Płaszowie 1942-1945 (Warsaw-Krakow: Instytut Pamięci Narodowej, 2009), 161-175.

19 Built in 1964 by architect Witold Cęckiewicz. In an interview I conducted with Cęckiewicz in October 2013, he told me that he did not recollect the source of funding or the originator of the memorialization 
of the former Zwangsarbeitslager in Ohrdruf (part of Michael Levin's War Story [1995]), asserting that in fact "we are made to see an unfathomable void that will not be dispelled." 20 The idea of "picturing nothing" also facilitates the ekphrasis of the black-and-white photograph called "Sobibór" from the cycle Deathly Still: Pictures of Former Concentration Camps by Dirk Reinartz (1995).21 Applying Baer's ideas to pictures that clearly do not display emptiness in any empirical sense seems to suggest that the fundamental quality of "non-sites of memory" is their invisibility, their transparency, in the sense that they do not hold the gaze of the passerby. Difficult to recognize, they then surprise us with their lack of identifying markers; our awareness of these spaces' connections to instances of mass murder, meanwhile, heightens our sense of absence and abandonment - our sense of emptiness. A number of photographic projects dedicated to representing non-sites of memory would later opt for a similar poetics, including some of Alan Cohen's series On European Ground (2001), Susan Silas' Helmbrechts Walk (1993-2003), and even Wojciech Wilczyk's photographs from There Is No Innocent Eye (2009) [Niewinne oko nie istnieje], meticulously made devoid of any human presence.

Baer's interpretations are exemplars of a very typical practice in dealing with genocide sites. Their reception is generally formatted by a particular minimalist and monochromatic aesthetic consistent with the poetics of the artworks - like Levin's and like Reinhartz's. Lanzmann spoke similarly about the places he filmed in Poland in an interview for Cahiers du Cinéma: "there was nothing at all, sheer nothingness, and I had to make a film on the basis of this nothingness." 22 The expectations of the viewers inform the work to such an extent that it sometimes goes as far as to sacrifice authenticity - so vital to Holocaust history - to preserve its ascetic style. ${ }^{23}$ Meanwhile, the stereotype of the monochrome is immediately undone, insofar as nature makes its way in the cognitive process from back- to foreground, where - compositionally - in the case of the representation of "non-sites of memory," it generally tends to be. The necessity of a reappraisal of over-exploited conventions of reception has been pointed out by Simon Shama, who writes that "we are

20 Baer, SpectralEvidence, 75 .

21 Dirk Reinartz, Deathly Still: Pictures of Former Concentration Camps (New York: Scalo Publishers), 1995

22 Stuart Liebman, Claude Lanzmann's Shoah: Key Essays (Oxford: Oxford University Press, 2007 ), 39.

23 One of the extras from Schindler's List interviewed in the video project Spielberg's List (2003) by Omer Fast, mentions that Spielberg's set required the reconstruction of prisoners' barracks, with new boards being painted gray despite the fact that in 1943 they would have looked exactly like the ones freshly delivered in 1992: new and light-colored. 
accustomed to think of the Holocaust as having no landscape - or at best one emptied of features and color, shrouded in night and fog, blanketed by perpetual winter, collapsed into shades of dun and grey [...]. It is shocking, then, to realize that Treblinka, too, belongs to a brilliantly vivid countryside." 24 Putting the static poetics of reception to one side, we run into elements that are inconsistent with the Holocaust: colors, sunshine, and the vibrant filling in of the field of observation that is nature.

Recent contributions of the newly non-anthropocentric humanities now equip us to better consider the properties of "non-sites of memory," beginning with the visible; that is, with the landscape: biotic and abiotic components of the local ecosystem. Nature, in the case of the spaces that interest me here, is the only immediate datum: if the site does still contain remnants of past tragedy, they are often hard to spot at first glance and may require some digging around in order to be discovered. Perceiving the intense, even lush layers of plant life demands the two steps just described: the deconstruction of the concept of "non-sites of memory" as places of voids, and the rejection of monochromatic poetics as the basic format of the imagination.

The question of whether biological material can provide insight into "nonsites of memory" leads in turn to more specific issues, such as the extent to which nature becomes representation, or even literally presentation in the sense of making the victims present. The two extremes in this debate are, on the one hand, the position that plant life is the worst enemy of remembering the victims, and on the other, the opposite: that nature is a faithful companion and suffering's most intimate witness. One of these stances is held by Armando, the Dutch painter and writer.

Born in 1929, Armando spent the years of World War II (and of his childhood) in Amersfoort, a township in which the Nazis placed a concentration camp. His experience of the silence and passivity that occurred alongside those atrocities has returned time and time again in his works. The landscape onto which the guilt of all of the "by-standers" has been projected has turned into a schuldig Landschap (guilty landscape). Armando's denouncement is a polyphonic soliloquy: "The edge of the forest, for example the trees towards the front, must have seen a thing or two. The trees in the back can hardly be blamed, they could never have seen anything. But the edge, the seam of the forest: that has seen it ..."25 Ernst van Alphen explains the position of the artist as follows: "The presence of the trees on that scene of violence, the continuity between the edge of the forest and the perpetrators of that violence,

\footnotetext{
24 Simon Schama, Landscape and Memory (New York: Vintage Books, 1996), 26 
enables the trees to be blamed. The trees are witnesses, but they don't testify. Their refusal to testify, to serve as a trace of "the war,' determines their guilt." The order of anthropomorphic nature is, then, radically distinguished from the order of the victims.

The reverse position is represented by Łukasz Surowiec, who presented a project entitled "Berlin-Birkenau" at the 2012 Berlin Biennale. A part of the work was the act of giving out birch seedlings from the site of the former Birkenau concentration camp. The artist explained his plan as follows: "I bring a live cemetery. The trees at Birkenau drink water from earth mixed with ashes and breathe the same air that bore the smoke from the burnt bodies. Those trees contain something of those people."26

Surowiec's bioart project is one of the works that initiate and foment the idea that plants, in absorbing the mineral remains of human beings as they grow, become something more than simply the representation of the victims' suffering by becoming witnesses at the cellular level-their presence metonymically restores the existence of those now absent. Anthropomorphizing trees, either planted or spontaneously arising on Holocaust sites, results in a next step, that of taking the metaphor literally: "if we actually think about the organic contents of the trees, we realize that they all contain within themselves the remains of the victims," writes Jacek Małczyński in his piece tellingly titled Trees: Living Monuments at the Museum and Place of Memory in Betzec. ${ }^{27}$ Trees are thus treated as transgenic objects - an extreme liberalization of a metaphor, since blending human with plant DNA is in fact an operation that must be carried out artificially in a lab. ${ }^{28}$ It is an approach that renders habitat not as witness, but rather as a way of permitting the victims to endure. ${ }^{29}$

26 An interview conducted by Daniel Miller, accessed July 27, 2012, http://www.krytykapolityczna. pl/7BerlinBiennale/SurowiecBerlinBirkenau/menuid-427.html.

27 lacek Małczyński, "Drzewa-Żywe pomniki w Muzeum-Miejscu Pamięci w Bełżcu," Teksty Drugie 1-2 (2009).

28 Jacek Małczyński writes about a "laboratory" art project by Gregore Tremmel and ShihoFukuhara entitled "Biopresence," accessed July 27, 2012, http://www.biopresence.com/description. $\mathrm{html}$. There are also similar commercial projects; cf. Ian Sample, "Firm Plans Human DNA Tree Memorial," The Guardian (April 30, 2004), accessed 28 July 2012, http://www.theguardian.com/ science/2004/apr/3o/genetics.highereducation.

29 Between these two limit points there are a number of intermediary interpretations also possible, of which I will mention only one here: Oskar Hansen's project of a "road memorial,"in which the artist, along with a group of others, proposed cutting across the terrain of the camp at Auschwitz with an asphalt road 65 meters across and conserving only those camp relics that could be found within the space of that road. The rest was to be consumed by nature. Jan Stanisław Wojciechowski cites an unpublished note written by Hansen: "The growing forest surrounding the "Road" is a kind of "watch" measuring the time that elapses since the tragic 


\section{Below}

Regardless of what position we take on what we find above ground, traces of the tragedy remain concealed below ground, and a full analysis of "nonsites of memory" would have to consider the space traditionally occupied by archaeology and geology. The difficulty of this research is crucially heightened by the fact that according to Judaic law, land containing the remains of victims of the Holocaust cannot be touched, being cemetery land. ${ }^{30} \mathrm{An}$ analysis of what is hidden beneath the plant layer appears to aim primarily at the discovery of relics - proofs of the existence of places of torture and of bodies or human ashes. I would argue that the materiality of these objects is more complicated than this.

In 2006, the Municipality of Krakow announced an architectural competition to develop the land of what was once the Płaszów camp. The team (Proxima) that won first place in the competition was asked to provide an inventory. The categories employed by the architects can enable us to imagine the "sub-plant" state of the "non-site of memory." Proxima presented the results of their research in ten charts: a geological map of the present state of the place; a map of Austrian remains from the First World War; a map reconstructing the borderlines of the pre-war Jewish cemeteries; a map of the concentration camp buildings from the Second World War; a map of extant camp relics; a map of postwar developments (roads, paths); and a map of recent technical installations (water pipes, electricity cables, etc., that now run through the camp's premises). The eighth map displays the ownership structure; the last-but-one pictures trees and shrubs; and the last map presents the proposed developments needed to complete the winning project.

These charts are a testament to how many discourses are at work within a single, topographically defined place: geographical, geodetic, geological,

events of the camp, so it's an expression of the triumph of life over death ... Then when you keep going you emerge from the "Road" into the open space of a field... You return to life, able to fully appreciate its value." Ian Stanisław Wojciechowski, "Oskara Hansena (i zespołu) projekt oświęcimskiego pomnika 'Drogi' wświetle jego teorii Formy Otwartej, "in Pamięć Shoah: Kulturowe reprezentacje i praktyki upamiętniania, ed. Tomasz Majewski and Anna ZeidlerJaniszewska ('́ódz: Wydawnictwo Officyna, 2011), 65.

30 Archeological investigations were conducted in preparation for the construction of the memorial site in Bełżec; cf. Małczyński, Drzewa, 211: "33 mass graves have been located. They take up a large part of the site. The minimally invasive method of drilling probes has been used." Sobibór was similarly investigated, see Andrzej Kola, "Sprawozdaniez archeologicznych badan na terenie b. obozu Zagłady Żydów w Sobiborze, ${ }_{r}$ Przeszłosć i Pamięć 3 (2000). Non-invasive Holocaust archaeology is a recent development; cf. Caroline Sturdy Colls, "Holocaust Archaeology: Archeological Approaches to Landscapes of Nazi Genocide and Persecution" lournal of Conflict Archaeology 7 (2012). 
historical, administrative and legal, technical (systems), biological, religious (the cemeteries existing on this land prior to the war), artistic (the development planned), as well as memory discourse (existing monuments). We can imagine maps charting the walking paths and pausing places for local residents (the discourse of "free time"), mapping the places specified by camp inmates in their private narratives (the discourse of idiosyncratic memory), and mapping the "phantasmatic" - local residents have their own tales and legends about the land from after the war. The camp land is also impinged upon by aggressive advertising by a nearby shopping mall that closes off the view and that also makes it possible to add to the above list, economic discourse (the discourse of consumption and trade).

The way that the Proxima Group has physically rationalized the confusion of orders on camp land brings to mind the notion of a palimpsest as a basic cognitive model allowing the increasing complexity of the site under consideration to be reckoned with. The figure of the palimpsest is built upon an idea of sedimentation (the buildup of successive planes) and provides a consistent synchronic model ${ }^{\mathbf{3 1}}$ in which individual categories are easy to separate, group, and read. (This is how the Proxima study is organized.)

As much as the quality of simultaneity certainly describes the state of the discourses interwoven in the fabric of the camp terrain in Płaszów, the project does not attain functional data storage or readability. Let us note, however, the way in which Proxima presented their study: the first map becomes lighter when the second map is placed on top of it, etc. Let us imagine, meanwhile, all the maps placed upon one another without any shading allowances: the chaos of the symbols would make any recognition of the properties of the site impossible. The researcher confronted not with the model, but rather with the object, standing in the middle of the terrain in question, is confronted with a cacophony of unstructured data (data that is in fact encoded and that requires training in order to be decoded, which impedes the activity of understanding still further.) The layeredness of the palimpsest, then, is merely an a priori cognitive construction allowing for the pictorial representation of the elements of the "non-site of memory" and is most certainly n o t its ontological characteristic.

Therefore, it might be more effective to refer to a "technical" description of a palimpsest. Greco-Roman etymology unites the words palin ("again") and

31 "The structural concept of the palimpsest is based on the text's ability to reveal explicitly its sources of precedent layers in order to make them totally visible and easily discernable," see Michał P. Markowski, "Wiping Out: The Palimpsest, the Subject, and the Art of Forgetting," edited by Bożena Shallcross and Ryszard Nycz (Frankfurt am Main: Peter Lang, 2011), 121. 
psao ("I scrape").32 Some of the elements that make up the physical contours of the Płaszów grounds seem to support the "leveling" quality of the palimpsest: layers do not simply get added to one another, but are rather always erasing what came before, leaving only traces of the existence of the previous layer. As a new layer of soil and vegetation covered over and destroyed the remnants of the camp's buildings, so the construction of the camp itself razed the structures that had been built on that land in the era of the First World War, and so, too, the current construction of apartment buildings has erased all traces of the SS barracks.

But it strikes me that the figure of the palimpsest, whether the palimpsest that accentuates layeredness and lastingness or the palimpsest that refers more to the act of destruction, is unable to productively back up any analysis of the "non-site of memory," primarily because of one characteristic shared by both versions; namely, the basic concept of order, the succession of individual elements, the particular "syntactic logic" of both models based on the idea of sequence, on relationships of cause and effect, and on the assumption that the basic elements of the system are discrete, unconnected and discernable. Meanwhile the reality of physical objects on the grounds of the camps turns the idea of "layeredness" upside down-part of the installation is underground, part of it above; the ruins of the barracks are at once overgrown (as when vegetation covers extant structural elements of the camp) and also partly not (as when vegetation is nearby or underneath these elements); the human remains may be underneath but also above the earth's surface. In addition, some architectural projects (for example, the reinforcement of the Krakow fortress) functionally belong to several maps (several discourses): the trenches must simultaneously be included in the categories of ruins of the beginning of the twentieth century and mass graves from 1944. Furthermore, in treating layers as stable space, the metaphor of the palimpsest does not explain what happens betwe en them: ${ }^{33}$ it does not, then, serve the purpose of describing those "dynamic," "mixed," "diffuse" objects that are, without a doubt, the "living" grounds of "non-sites of memory."

\section{Prism}

The contested sites of genocide and atrocity - I repeat - cannot be explained with the use of concepts based on the logic of a sentence. The particular

32 Cf. Justyna Beinek, "Inscribing, Engraving, Cutting: The Polish Romantic Album as Palimpsest, in The Effect of Palimpsest: Culture, Literature, History, 29.

33 Ryszard Nycz, "The Palimpsest and the Spiderweb: Two Dimensions of the Textualisation of Experience ${ }_{r}{ }^{n}$ in The Effect of Palimpsest, 23. 
"mixed" character of "non-sites of memory" requires us to seek out metaphors from among terms suggesting disorder, and especially the type of disorder in which biological and non-biological elements are mixed, along with manmade items and natural elements, all of it in a state of constant agitation, of ongoing change. Elements disintegrate and are shuffled around, grow and die, are moved (e.g., by architects investigating the terrain, by visitors, by animals, by prisoners customarily sent in the spring to do light logging). Thus the metaphor I seek would need to include the idea of confusion and leftovers, of change and remaining, and perhaps the fullest reservoir of suitable ideas might be found in "rubbish theory."

What unites the "non-site of memory" with the "garbage heap" is not only the metaphor of the "rubbish dump of history," which we could no doubt use for places like Płaszów, not only the habit of littering in deserted places, but their shared state of "potentiality" and "indeterminacy." If Jonathan Culler is correct that "as the transient moves towards rubbish, it can either be torn down to make way for something new (this is the transient view, the view from the system of transients) or else salvaged as durable: rebuilt, reconstructed." ${ }^{34}$ The material contents of the "non-site of memory" possess a similar dual dynamic: the camp's remains, as well as human remains, undergo a process of decomposition, becoming soil for the plants, though they might also be preserved if the locale is selected for conservation and turned into a "lieu d'histoire." Yet it is difficult to ignore the fact that some elements of rubbish theory preclude its usage for "non-sites of memory." Firstly, it echoes the rhetoric of the perpetrators who originally sent "human garbage" off to these camps in the first place. Secondly, in order for it to be "rubbish," the locale must become useless and "inferior" within the system of exchange. ${ }^{35}$ The most important components of "non-sites of memory," human remains, simply cannot be evaluated in terms of an economic system, nor can there be any idea of referring to them as "trivial."

Metaphors with their provenance in the language of the natural sciences may be more productive, including the (also Adornian) term "detritus," with its connotation of an unordered accumulation of many elements and the movement of their interaction, as well as the effect of their acting: departure, destruction, forgetting. ${ }^{36}$ In biology, detritus is any form of non-living organic material, be it the bodies or components of dead organisms or the matter

34 Jonathan Culler, "Junk and Rubbish: A Semiotic Approach," Diacritics 15 (Fall 1985): 9.

35 lbid., 5

36 Zafar Reshi and Sumira Tyub, Detritus and Decomposition in Ecosystems (Delhi: New India Publisher 2007), 1. 
discarded by living organisms, such as feces. ${ }^{37}$ Adorno utilized the term in a context convergent with the topic of this article insofar as it was connected with the operation of memory disturbed by the "detritus of things." 38 Detritus is synonymous in Adorno with the indiscriminate magma of stimuli brought to us by popular culture. Understood literally, "biologically," it carries connotations that are useful in thinking about the problematic of the "non-site of memory": the unordered accumulation of many elements, the movement of their interactions, as well as the effect of their activities: waste, ruin, homogenization. It emphasizes the influence on the surrounding community. (For biologists and ecologists, detritus has a major role in the proper functioning of the ecosystem.)

Detritus is thus the arena in which dead matter (the past) becomes transformed into fertile soil that is able to give rise to new life. In this sense, it serves to heal: in the case of "non-sites," what has been forgotten may need to have been forgotten in order for the surrounding areas to continue to live. The metaphor of detritus would thus describe the positive component of the decomposition of memory occurring at "non-sites of memory" and the restorative significance of this process for the communities residing around these "non-sites." On the other hand, the particularity of the "non-lieu de mémoire" is its conjunction of "detritus" with the opposite of this - not everything falls apart, and the very notion of visiting the places mentioned here is tied to the conviction that there is still evidence here incriminating the perpetrators - even if this evidence takes the form of a person capable of recalling the crime.

The material reality of "non-sites of memory" could also be described by means of an idea rejected by Giorgio Agamben in his Remnants of Auschwitz. "Hypostasis," in its original Greek meaning, "is a substratum, deposit, or sediment left behind as a kind of background or foundation by historical processes of subjectificaton and desubjectification."39 I am particularly interested here in this definition's mobilization of what I was pointing out in analyzing GP Proxima's charts: the multitude of discourses clashing on the post-camp terrain of Płaszów. The short-circuiting, the collision, or even the less violent compounding of the space's external qualities that produce its sedimentary, residual character as a "collection of traces" would direct our attention

37 Ibid.

38 Tia DeNora, After Adorno: Rethinking Music Sociology (Cambridge: Cambridge University Press, 2003), 77 .

39 Giorgio Agamben, Remnants of Auschwitz: The Witness and the Archive, trans. Daniel HellerRoazen (New York: Zone Books, 1999), 158. 
to geology, which has lately become a participant in historical discourses. ${ }^{40}$ The term "anthropocene" has arisen to define a period in which human activity has become defining in the shaping of the earth, so that the "eternal humanist distinction between the history of humanity and natural history" $\mathbf{4 1}$ has collapsed before our very eyes. "Non-sites of memory" may, then, serve as spheres in which one can actually observe this intermingling of the traditional human and natural orders. In some of them, one can literally watch the functioning of "man as new geological force" - especially in Płaszów, built near a quarry and also working during the war as a place that intervened in the land's own structure. During the First World War, soldiers disrupted the limestone present here by digging trenches; later, camp prisoners were forced to dig out cellars, break down rock, and remove the ensuing rubble. On these "non-sites of memory" natural history - the history of the rocks, trees, water-becomes an essential component of human history, making theoretically possible a discussion that would exceed the historical order.

Thus, the final metaphor I wish to propose here for the "non-site of memory" comes from the reservoir of geology. The term I have in mind is "prism." In Polish, "pryzma" is used to designate compost; that is, the place for organic garbage. In this term, therefore, both rubbish theory and detritus come into play. The term also holds the energy of hypostasis; i.e., the sediment necessary for development, growth, and change. Geology, meanwhile, defines prism, above all, as the "accretionary prism." This is an area of sedimentation produced by materials sloughed off by the force generated by friction between the largest tectonic plates, transferred and then left in the form of a wedge wherever it was that the tectonic movements ceased.

This definition of prism thus also incorporates a palimpsestic, continuous "scraping." Rock and organic material (e.g., from the bottom of the sea) are combined in no order and expelled from their original location as the result of overwhelming force, geological "violence." The prism is thus organic and nonorganic, is "marred" and "illegible." It is produced by the activity of external forces, which can be compared to the activity of external discourses: history, politics, economy, memory. "The wedge," the physical presence of the object, does not allow itself to be dominated by these discourses, leaving the unsettling feeling that sweeps up the visitor, the feeling that there is still something there that threatens the organized order. The more common English meaning of the word prism, ${ }^{42}$ i.e., an object that separates white light into a spectrum of

\footnotetext{
40 Cf. Dipesh Chakrabarty, "The Climate of History: Four Theses," Critical Inquiry 2 (2009)

41 Ibid., 201.

42 Until recently, this meaning also existed in Polish.
} 
colors, alsogenerates a particular kind of metaphorical strength: "non-sites of memory" are locations deconstructing all homogenizing imaginaries purporting to understand them. They refract and complicate superficially monological discourse - both the discourse around itself and perhaps also the existing discourse on genocide sites in general.

\section{A Question in Lieu of a Conclusion}

That Lanzmann, in rejecting the notion of the "lieu de mémoire," added a negating particle to the first rather than to the second component of Nora's term ought to give us pause, for it could also be argued that in the locales he films, it is memory, not the site, that is deficient. Edward Relph was a precursor to Marc Augé and student of Martin Heidegger. His Place and Placelessness (1976) tied "placelessness" with a particular quality of topographical sites that strips the visitor of his or her sense of being an "existential participant" in a space of "givenness" for life. (I will bracket here for the moment the question of the modernity of the places described by Relph.) Baer, describing the effect of Levin's photograph, writes that it shows the "landscape without us." 43 "Nonsites of memory" are, then, not-for-life; they are always sentenced to death. The readily discernable other side of this phrasing is the critique of - even the indignation in the face of - the vacancy, the unmarkedness, the nondescriptness of these spaces. "Non-sites" ought instead to be cordoned off by some sort of "line" indicating their extent, allowing for the demarcation of the space of our symbolic engagement. Lanzmann's thinking clearly subscribes to this desire for demarcation: in an interview with François Gantheret for La Nouvelle Revue de Psychanalyse, in which he utilized the term "non-lieux de mémoire," he talked about arriving in Sobibór and meeting an old railway man. Lanzmann reconstructed the conversation as follows:

"Please show me. Please show me where the camp started."

"Okay," he said. "I'll show you." After taking a few steps he turned to me and said, "Okay, here there was a wood support, and then here was the next one." And I see myself crossing that line and saying, "Here I'm inside the concentration camp." I stepped back three meters. "And here I'm outside of the camp. On that side, you have death. On this side, life."44

43 Baer, Spectral Evidence, 75 .

44 Cited (in a different translation reversing the order of the last two sentences of this passage) in Richard Brody, "Claude Lanzmann on 'Shoah," The New Yorker (December 10 2010), http:// www.newyorker.com/online/blogs/movies/2010/12/claude-lanzmann-on-shoah.html; cf. Au 
It is hard for me to accept the dialectical nature of this "here you have death, there you have life." If you look at the actual "non-sites of memory" from the perspective of Eastern Europe, the limiting "line" that Lanzmann requires was never so obvious. The line was, for the Eastern European population, permeable (although the degree of its permeability was, of course, different for different groups of people), far more permeable than to the citizens of countries in the West, due to radical differences in the forms of Nazi occupation. In any case, those limits that were wooden structures did not defend against death: at any moment, the whim of any of the perpetrators might cast anyone at all over onto the "side of death." That is why, given the location of my point of view between Moscow and Berlin, it seems to me that it is necessary in the face of "non-sites of memory" - which perhaps ought to be given another name - to ask a different set of questions. Access to them, as they are not yet fully articulable, would consist of deconstructing the third principle of the conceptualization of places of genocide: dialectical separation. Standing with a camera in the forests of Sobibór, at the clearing in Ohrdruf, in the landscape of Płaszów, we are there, we are at the non-site, we enter onto that terrain, consciously or unconsciously invading a place of death with life. The "non-site of memory" turns out to be the "landscape with us." In order to comprehend the "fundamental significance" of these sites, we need to try and understand how the forces of memory and forgetting together affect this space, how the vibrancy of these places coexists with their moribundity; hence, their "organic-nonorganic" character, inextricable.

Stepping out of the discursive frameworks set out above for a moment, I would like to ask a more basic question of those sites "of fundamental significance": where do we actually stand in relation to them? If not on the outside and not on the inside - then where? Are we excluded from them, or sucked into their untamed life after/in trauma? What are we to do, here in this part of Europe, as we enter onto "non-sites of memory," theoretically "unlivable," but in practice so shamelessly alive?

Translation:Jennifer Croft 